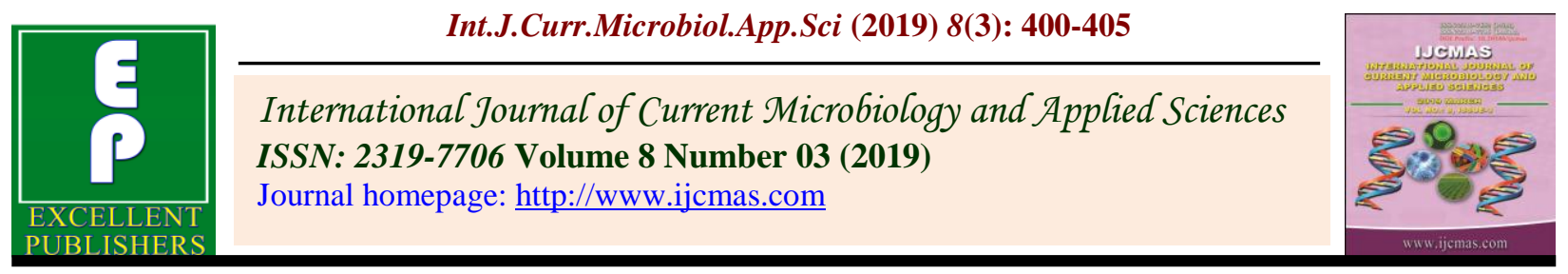

Original Research Article

https://doi.org/10.20546/ijcmas.2019.803.050

\title{
Effect of Organic Manures, Fertilizers and their Combinations on Growth, Yield and Quality of Radish (Raphanus sativus L.) cv. Japanese White
}

\author{
Kaluram Khede, Ajay Kumawat* and Diksha Tembare
}

Department of Vegetable Science, Rajmata Vijayaraje Scindia Krishi Vishwavidyalaya, College of Agriculture, Indore-452 001, Madhya Pradesh, India

*Corresponding author:

\begin{tabular}{|l|}
\hline Ke y w o r d s \\
Radish, \\
Raphanus sativus, \\
Organic manures, \\
Fertilizers
\end{tabular}

\section{A B S T R A C T}

The present investigation entitled "Effect of Organic Manures, Fertilizers and their Combinations on Growth, Yield and Quality of Radish (Raphanus sativus L.) cv. Japanese White" was conducted at the Department of Horticulture, College of Agriculture, Indore (M.P.) during the year 2017-2018. The experimental materials for the present investigation were comprised of treatments viz., Control- No organic manure /fertilizers, Recommended dose of fertilizer $\left(100 \mathrm{Kg} \mathrm{N}, 80 \mathrm{Kg} \mathrm{P}_{2} \mathrm{O}_{5}\right.$ and $\left.50 \mathrm{Kg} \mathrm{K}_{2} \mathrm{O} \mathrm{ha}{ }^{-1}\right), 50 \% \mathrm{RDF}+50 \% \mathrm{FYM}$ of Recommended Dose, 50\% RDF + 50\% Vermicompost, 50\% RDF + 50\% Poultry manure, $50 \% \mathrm{RDF}+25 \% \mathrm{FYM}+25 \%$ Vermicompost, $50 \% \mathrm{RDF}+25 \% \mathrm{FYM}+25 \%$ Poultry manure, $50 \%$ RDF $+25 \%$ Vermicompost $+25 \%$ Poultry Manure, $75 \% \mathrm{FYM}+25 \% \mathrm{RDF}$, $75 \%$ Vermicompost $+25 \%$ RDF, $75 \%$ Vermicompost $+25 \%$ RDF, $75 \%$ Poultry Manure + $25 \% \mathrm{RDF}$ and $25 \%$ of each RDF $+25 \%$ FYM $+25 \%$ Vermicompost $+25 \%$ Poultry Manure, laid out in Randomized Block Design with three replications. The plant height $(32.43 \mathrm{~cm})$, Length of leaves (29.37), fresh weight of root $(119.73 \mathrm{~g})$ and Dry weight of root $(20.36 \mathrm{~g})$, root length $(22.83 \mathrm{~cm})$, diameter of root $(3.87 \mathrm{~cm})$, average weight of root $(119.73 \mathrm{~g})$ and yield of root $\left(498.89 \mathrm{q} \mathrm{ha}^{-1}\right)$, total soluble solids $\left(5.09^{0} \mathrm{Brix}\right)$ and fiber content $(749.87 \mathrm{mg})$ recorded maximum values with respectively in treatment $\mathrm{T}_{8}(50 \%$ $\mathrm{RDF}+25 \%$ Vermicompost $+25 \%$ Poultry Manure). The number of leaves (13.23) recorded maximum values with respectively in treatment $\mathrm{T}_{4} 50 \% \mathrm{RDF}+50 \%$ Vermicompost.

\section{Introduction}

Radish (Raphanus sativus L.) belongs to the family Brassicaceae and it has $2 n=18$ chromosomes. It is a popular root vegetable in both tropical and temperate regions. It can be cultivated under cover for early production but large scale production in field is more common in Haryana, West Bengal, Punjab,
Bihar, Assam, Madhya Pradesh and other some state of India. In Madhya Pradesh, radish is grown in 10440 ha with a production of 153270 tones (Anonymous, 2016-17).

Radish is grown for their young tender tuberous roots which are consumed either cooked or raw. The radish leaves are rich in minerals and vitamin A (5 IU) and vitamin C 
$(15 \mathrm{mg})$ and are roots rich in potassium (138 $\mathrm{mg}$ ) and calcium (50 mg). It has got refreshing and diuretic properties. In homeopathy, it is used for neurological, headache, sleeplessness and chronic diarrhea. The roots are also useful in urinary complaints and piles. The leaves of radish are good source for extraction of protein on a commercial scale and radish seeds are potential source of non-drying fatty oil suitable for soap making illuminating and edible purposes. The edible part of radish is modified root which develops form both primary root and hypocotyls. The pungency in radish is due to the presence of volatile isothiocynates.

\section{Materials and Methods}

The experiments were carried out during the Rabi season, 2017-18, at the Research Farm, Department of Horticulture, College of Agriculture, Indore (M.P.). Geographically Indore is situated in Malwa plateau region in the Western part of the state of Madhya Pradesh at an altitude of 555.5 meters above mean sea level (MSL). It is located at latitude $22^{\circ} 43^{\prime} \mathrm{N}$ and longitude of $75^{\circ} 66^{\prime} \mathrm{E}$. It has subtropical climate having a temperature range of $29^{\circ} \mathrm{C}$ to $41^{\circ} \mathrm{C}$ during summer and $7^{\circ} \mathrm{C}$ to $23^{\circ} \mathrm{C}$ in winter season with mean relative humidity of $30-85 \%$. The rainfall in the region has been mostly inadequate and erratic in most of the recent past seasons. Late commencement, early withdrawal of monsoon and occurrence of two to three dry spells during the rainy season are the common features. The mean annual average rainfall is $954 \mathrm{~mm}$. The soil of experimental field was medium black clay in texture with uniform topography. The experiment consisted of 12 treatments in combinations of recommended dose of Recommended dose of fertilizer with bio-fertilizers. The various treatments with their symbols are presented in Table 1. The experiment was laid out in randomized block design with three replications. Different organic manures such as farmyard manure, vermicompost, and Poultry manure were incorporated in the field before sowing as per the treatments. Japanese White variety of radish was grown using the spacing of $30 \times 10$ $\mathrm{cm}$. appropriate standard and uniform agronomical / cultural practices and plant protection measures were adopted for raising healthy crop. Observations were recorded under investigation i.e. the plant height, Length of leaves, fresh weight of root, Dry weight of root, root length, diameter of root, average weight of root, yield of root, total soluble solids (TSS) and fiber content. All the above mentioned observations were recorded from five plants were randomly selected from each treatment for determining various growth and yield parameters.

\section{Results and Discussion}

A perusal of data (Table 2) revealed that application of plant nutrients through recommended dose of Recommended dose of fertilizer with bio-fertilizers significantly affected the growth and yield attributes of radish. It is evident from the data that application of $50 \% \mathrm{RDF}+25 \%$ Vermicompost $+25 \%$ Poultry Manure (T8) resulted significantly maximum plant height $(32.43 \mathrm{~cm})$ Followed by $\mathrm{T}_{4}(50 \% \mathrm{RDF}+50 \%$ Vermicompost) (29.90). The increase in height of plant by the use of vermicompost with integration of NPK may be due to beneficial influence of nitrification inhibition properties of vermicompost in the soil. Besides, it may also be due to rapid elongation and multiplication of cell in the presence of adequate quantity of nitrogen. Similar results were reported by Singh et al., (2016) and Verma et al., (2017). The number of leaves (13.23 per plant) significantly superior treatment $\mathrm{T}_{4} \quad(50 \% \mathrm{RDF}+50 \%$ Vermicompost). Followed by (12.60 per plant) $\mathrm{T}_{8}(50 \% \mathrm{RDF}+25 \%$ Vermicompost $+25 \%$ Poultry Manure). Highest number of leaves in 
$\mathrm{T}_{4}(50 \% \mathrm{RDF}+50 \%$ vermicompost) due to slow release of nutrients through vermicompost thus enriching available nutrient pool of the soil that resulting in more number of leaves plant ${ }^{-1}$ (Bhattarai and Maharjan, 2013). Similar findings have been reported by Kumar et al., (2014) and Mohmmad et al., (2015) in radish.

The maximum and significantly higher length of leaves (29.37) was recorded in $\mathrm{T}_{8}(50 \%$ $\mathrm{RDF}+25 \%$ Vermicompost $+25 \%$ Poultry Manure). Followed by (28.40) $\mathrm{T}_{4}(50 \% \mathrm{RDF}+$ $50 \%$ Vermicompost), $\mathrm{T}_{10}(25 \% \mathrm{RDF}+75 \%$ Vermicompost). The vegetative parameters like leaf length and numbers of leaves plant ${ }^{-1}$ were greatly influenced by organic source. Similar findings have been reported by Kumar et al., (2014) in radish, Vijaykumari et al., (2012) and Jat et al (2017). The maximum and significantly higher fresh weight of root $(119.73 \mathrm{~g})$ was recorded in $\mathrm{T}_{8}(50 \% \mathrm{RDF}+$ $25 \%$ Vermicompost $+25 \%$ Poultry Manure) Followed by (113.73 g) $\mathrm{T}_{4}(50 \% \mathrm{RDF}+50 \%$ Vermicompost) Similar findings have been reported by Uddain et al., (2010), Mehwish et al., (2016), Vijaykumari et al., (2012) and Kumar et al., (2014). The maximum and significantly higher dry weight of root (20.36 g) was recorded in $\mathrm{T}_{8}(50 \% \mathrm{RDF}+25 \%$ Vermicompost $+25 \%$ Poultry Manure). Followed by $(19.33 \mathrm{~g}) \mathrm{T}_{4}(50 \% \mathrm{RDF}+50 \%$ Vermicompost) Similar findings have been reported by Mehwish et al., (2016) and Kumar et al., (2014). Higher length of root (22.83) was recorded in $\mathrm{T}_{8}(50 \% \mathrm{RDF}+25 \%$ Vermicompost $+25 \%$ Poultry Manure). Followed by (22.43) $\mathrm{T}_{4} \quad(50 \%$ RDF + $50 \%$ Vermicompost) Decrease in bulk density and increase in porosity and water holding capacity of the soil due to organic manures might have contributed in increasing the length of root the plants. The increase in length of root may be attributed to solubilization of plant nutrients by addition of poultry manure and vermicompost leading to increase uptake of NPK. Finding corroborates with their results obtained by Rajan and Mahalakshmi (2007) and Kumar et al., (2014).

The maximum and significantly diameter of root was (3.87) recorded in $\mathrm{T}_{8}(50 \% \mathrm{RDF}+25$ $\%$ Vermicompost $+25 \%$ Poultry Manure). Followed by (3.73) $\quad \mathrm{T}_{4} \quad(50 \%$ RDF + $50 \%$ VermicompostThese findings are in agreement with those reported by Vijayakumari et al., (2012), Uddain et al., (2010) and Kumar et al., (2014) in radish.

Table.1 Treatments detail with their symbol

\begin{tabular}{|l|l|l|}
\hline S. No. & Treatment & Symbol \\
\hline 1. & $\begin{array}{l}\text { Control- No organic manure /fertilizers } \\
\text { Recommended dose of fertilizer (100 Kg N, } 80 \mathrm{Kg} \mathrm{P}_{2} \mathrm{O}_{5} \text { and } 50 \mathrm{Kg} \mathrm{K} \mathrm{K}_{2} \mathrm{O} \\
\text { ha-1) }\end{array}$ & $\mathrm{T}_{1}$ \\
\hline 2. & $\mathrm{~T}_{2}$ \\
\hline 3. & $50 \% \mathrm{RDF}+50 \%$ FYM of Recommended Dose & $\mathrm{T}_{3}$ \\
\hline 4. & $50 \% \mathrm{RDF}+50 \%$ Vermicompost & $\mathrm{T}_{4}$ \\
\hline 5. & $50 \% \mathrm{RDF}+50 \%$ Poultry manure & $\mathrm{T}_{5}$ \\
\hline 6. & $50 \% \mathrm{RDF}+25 \% \mathrm{FYM}+25 \%$ Vermicompost & $\mathrm{T}_{6}$ \\
\hline 7. & $50 \% \mathrm{RDF}+25 \% \mathrm{FYM}+25 \%$ Poultry manure & $\mathrm{T}_{7}$ \\
\hline 8. & $50 \% \mathrm{RDF}+25 \%$ Vermicompost + 25\% Poultry Manure & $\mathrm{T}_{8}$ \\
\hline 9. & $75 \% \mathrm{FYM}+25 \% \mathrm{RDF}$ & $\mathrm{T}_{9}$ \\
\hline 10. & $75 \%$ Vermicompost + 25\% RDF & $\mathrm{T}_{10}$ \\
\hline 11. & $75 \%$ Poultry Manure + 25\% RDF & $\mathrm{T}_{11}$ \\
\hline 12. & $\begin{array}{l}25 \% \text { of each RDF }+25 \% \mathrm{FYM}+25 \% \text { Vermicompost }+25 \% \text { Poultry } \\
\text { Manure }\end{array}$ & $\mathrm{T}_{12}$ \\
\hline & & \\
\hline
\end{tabular}


Table.2 Effect of organic manures, fertilizers and their combinations on growth, yield and quality of radish (Raphanus sativus L.) cv. Japanese White

\begin{tabular}{|c|c|c|c|c|c|c|c|c|c|c|c|}
\hline Treatment & $\begin{array}{l}\text { Plant } \\
\text { height } \\
\text { (cm) }\end{array}$ & $\begin{array}{l}\text { Number } \\
\text { of leaves } \\
\left(\text { plant }^{-1}\right)\end{array}$ & $\begin{array}{l}\text { Length } \\
\text { of } \\
\text { leaves } \\
\text { (cm) }\end{array}$ & $\begin{array}{l}\text { Fresh } \\
\text { weight of } \\
\text { root }(g)\end{array}$ & $\begin{array}{l}\text { Dry } \\
\text { weight } \\
\text { of root } \\
\text { (g) }\end{array}$ & $\begin{array}{l}\text { Length } \\
\text { of root } \\
(\mathrm{cm})\end{array}$ & $\begin{array}{l}\text { Diameter } \\
\text { of root } \\
(\mathrm{cm})\end{array}$ & $\begin{array}{l}\text { Average } \\
\text { weight of } \\
\operatorname{root}(g)\end{array}$ & 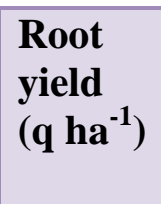 & $\begin{array}{l}\text { Total } \\
\text { soluble } \\
\text { solids } \\
\left({ }^{0} \text { Brix) }\right.\end{array}$ & $\begin{array}{l}\text { Fiber } \\
\text { content } \\
(\mathbf{m g} / \mathbf{1 0 0 g})\end{array}$ \\
\hline $\mathbf{T}_{1}$ & 19.37 & 9.37 & 16.77 & 48.70 & 8.28 & 16.27 & 2.03 & 48.70 & 202.92 & 3.67 & 488.87 \\
\hline$T_{2}$ & 24.87 & 11.20 & 22.96 & 91.17 & 15.50 & 20.97 & 2.83 & 91.17 & 379.86 & 4.27 & 545.83 \\
\hline $\mathbf{T}_{3}$ & 25.30 & 11.60 & 23.33 & 92.23 & 15.68 & 21.23 & 3.20 & 92.23 & 384.31 & 4.33 & 556.03 \\
\hline $\mathbf{T}_{4}$ & 29.90 & 13.23 & 28.40 & 113.73 & 19.33 & 22.43 & 3.73 & 113.73 & 473.89 & 4.93 & 676.20 \\
\hline$T_{5}$ & 26.17 & 11.90 & 24.83 & 96.50 & 16.41 & 21.43 & 3.40 & 96.50 & 402.08 & 4.40 & 580.87 \\
\hline$T_{6}$ & 27.40 & 12.53 & 25.90 & 99.43 & 16.90 & 22.27 & 3.53 & 99.43 & 414.31 & 4.60 & 618.37 \\
\hline $\mathbf{T}_{7}$ & 26.87 & 12.30 & 25.33 & 98.77 & 16.79 & 21.73 & 3.50 & 98.77 & 411.53 & 4.47 & 602.43 \\
\hline$T_{8}$ & 32.43 & 12.60 & 29.37 & 119.73 & 20.36 & 22.83 & 3.87 & 119.73 & 498.89 & 5.09 & 749.87 \\
\hline $\mathbf{T}_{9}$ & 23.77 & 9.97 & 22.27 & 89.37 & 15.19 & 19.23 & 3.32 & 89.37 & 372.36 & 4.03 & 501.97 \\
\hline $\mathbf{T}_{10}$ & 28.47 & 12.57 & 26.47 & 111.93 & 19.03 & 22.33 & 3.57 & 111.93 & 466.39 & 4.73 & 647.83 \\
\hline $\mathbf{T}_{11}$ & 24.47 & 10.83 & 22.77 & 89.90 & 15.28 & 20.70 & 2.53 & 89.90 & 374.58 & 4.20 & 518.97 \\
\hline $\mathbf{T}_{12}$ & 24.20 & 10.20 & 22.53 & 89.47 & 15.21 & 19.70 & 2.43 & 89.47 & 372.78 & 4.13 & 507.10 \\
\hline SEm \pm & 1.18 & 0.53 & 1.00 & 3.07 & 0.64 & 0.94 & 0.14 & 3.07 & 12.80 & 0.19 & 25.42 \\
\hline CD at $5 \%$ & 3.47 & 1.57 & 2.94 & 9.01 & 1.87 & 2.76 & 0.43 & 9.01 & 37.55 & 0.55 & 74.54 \\
\hline
\end{tabular}


Highest total soluble solids was (5.09) found with treatment $\mathrm{T}_{8} \quad(50 \% \mathrm{RDF}+25 \%$ Vermicompost $+25 \%$ Poultry Manure) Followed by (4.93) $\mathrm{T}_{4}(50 \% \mathrm{RDF}+50 \%$ Vermicompost), It might be due to accumulation of more reserve substances in root. Similar results have been also reported by Sunandarani and Mallareddy (2007) and Singh et al., (2016), Sharma et al., (2013).

Highest fiber content was (749.87) found with treatment $\mathrm{T}_{8} \quad(50 \% \mathrm{RDF}+25 \%$ Vermicompost $+25 \%$ Poultry Manure) Followed by (676.20) $\mathrm{T}_{4}$ (50\% RDF $+50 \%$ Vermicompost), $\mathrm{T}_{10}(25 \% \mathrm{RDF}+75 \%$ Vermicompost).

It may be concluded from the finding of the present study that among the different treatments, $\mathrm{T}_{8} \quad(50 \% \mathrm{RDF}+25 \%$ Vermicompost $+25 \%$ Poultry Manure) showed in the highest growth, yield and quality parameters of radish and it is closely followed by treatment $\mathrm{T}_{4}(50 \% \mathrm{RDF}+50 \%$ poultry manure), for the characters like growth, yield and quality parameters of radish.

\section{References}

Anonymous (2016-17). www.nhb.gov.in Baloch, P.A., Uddin, R., Nizamani, F.A., Solangi, A.H. and Siddiqui, A.A. (2014). Effect of nitrogen, phosphorus and potassium fertilizers on growth and yield characteristics of radish (Raphinus sativus L.) AmericanEurasian J. Agric. \& Environ. Sci. 14(6): 565-569.

Bhattarai, B. P. and Maharjan, A. (2013). Effect of organic nutrient management on the growth and yield of carrot (Daucus carota L.) and soil fertility status. Nepalese J. Agric. Sci. 11:1625.
Degwale, A. (2016) Effect of vermicompost on growth, yield and quality of garlic (Allium sativum L.) In enebse sar midir district, Northwestern Ethopia. J. Natural Sci. Res. 6 (3): 2224-3186.

Jat, P.K., Singh S.P., Devi S., Mahala P., and Kumar M. (2017). Effect of organic, inorganic fertilizers and plant densities on performance of radish (Raphanus sativas L.), S. K. N. Agriculture University, Jobner, Rajasthan, India I.J.S.R. 7(2): 261- 266

Kumar, S., Maji, S., Kumar, S. and Singh, H. D. (2014). Efficacy of organic manures on growth and yield of radish (Raphanus sativus L.) cv. Japanese White. Inter. J. PlantSci. 9(1): 57-60.

Mehwish K., Jilani M.S., Waseem K., and Sohail M. (2016). Effect of organic manures and inorganic fertilizers on growth and yield of radish (Raphanus sativus L.) Pakistan J. Agric. Res. 29(4)

Mohmmad K., Yadav, B.K. and Yadav, M.P. (2015). Studies on the effect of integrated nutrient management on growth and yield attributes of radish (Raphanus sativus $\quad$ L.). Ann. of Hort. 8 (1): 81-83

Rajan, M.R. and Mahalakshmi, R. (2007). Effect of vermicompost prepared from hotel wastes on growth and production of radish and cowpea. Environment and Ecology, 25S (Special4): 11941197

Sharma, U.G., Vihol, N.J. And Chavda, J.C. (2013) Influence of plant density and nutrient management on growth, yield and quality of radish (Raphanus sativus L.) cv. 'PUSA CHETKI' Asian J. Hort., 8(2): 671-676.

Singh V., Naseeruddin K.H. and Rana D.K. (2016). Effect of organic manures on growth, yield and quality of radish (Raphanus sativus L.) cv. pusa desi H.N.B. Garhwal Uni ver sity, 
Srinagar, Uttarakhand, 246174, Hort Flora R.S. 5(2): 129-133.

Sunandarani, N. and Mallareddy, K. (2007). Effect of different organic manures and inorganic fertilizers on growth, yield and quality of carrot (Daucus carota L.). Karnataka J. Agric. Sci. 20 (3): 686- 688.

Verma U.K., Kumar R., Kumar A., Kumar S. and Prajapati M.K. (2017). Integrated effect of organic manures and inorganic fertilizers on growth, yield and yield attributes of Radish CV. Kalyanpur safed Journal of Pharmacognosy and Phytochemistry; 6(6): 826-828.

Vijayakumari, B., Sasikala, V. and Poornima, C.P. (2012). Effect of organic and inorganic manures on biometric and yield parameters of radish (Raphanus savitus L.) cv. PUSAPHEPKI. Int. J. Plant Sci. 7(1): 130-134.

\section{How to cite this article:}

Kaluram Khede, Ajay Kumawat and Diksha Tembare. Effect of Organic Manures, Fertilizers and their Combinations on Growth, Yield and Quality of Radish (Raphanus sativus L.) cv. Japanese White. Int.J.Curr.Microbiol.App.Sci. 8(03): 400-405.

doi: https://doi.org/10.20546/ijcmas.2019.803.050 